
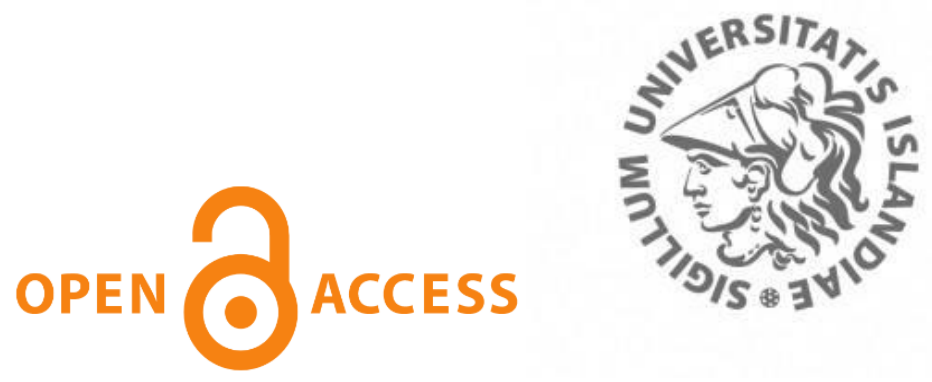

Op Opin vísindi

This is not the published version of the article / Detta er ekki útgefna útgáfa greinarinnar

Author(s)/Höf.: $\quad$ Svanborg Rannveig Jónsdóttir

M. Allyson Macdonald

Title/Titill: $\quad$ The feasibility of innovation and entrepreneurial education in middle schools

Year/Útgáfuár: $\quad 2019$

Version/Útgáfa: Post-print

Please cite the original version:

Vinsamlega vísið til útgefnu greinarinnar:

Jónsdóttir, S.R. and Macdonald, M.A. (2019), "The feasibility of innovation and entrepreneurial education in middle schools", Journal of Small Business and

Enterprise Development, Vol. 26 No. 2, pp. 255-272. https://doi.org/10.1108/JSBED08-2018-0251

Rights/Réttur:

Copyright $\odot$ 2018, Emerald Publishing Limited 


\section{The feasibility of innovation and entrepreneurial education in middle schools}

\section{Research paper}

Key words: social ecology, system interaction, teacher role, teacher

efficacy, innovation and entrepreneurial education.

Purpose

The purpose of this research is to construct a means of assessing the feasibility of implementing innovation and entrepreneurial education (IEE) in schools. The study focuses on teaching IEE in middle school (grades 5-7).

Design

Data were collected from six middle school teachers in three Icelandic compulsory schools. They include documentary evidence, on-site observations, and semistructured interviews with teachers and principals. Data were subjected to the method of constant comparison. A model of nested systems provided concepts to create categories for a general rubric of feasible IEE development, the SERIES (social ecological rubric in innovation and entrepreneurship in school).

\section{Findings}

Profiles of the six IEE teachers emerged during data collection. Teachers found some IEE methods challenging, especially „standing back“ allowing students freedom and agency. Implementation was fragile when IEE developed without support from neighbouring systems. In all three schools the weakest connections were with the exosystem (general views in society).

\section{Conclusions}

The range of knowledge, skills and competences that emerged in the data could be discussed with teachers as a source of professional development. The application of the SERIES approach can benefit policy, research and practice and similar rubrics can provide a valuable assessment approach in other curriculum areas.

\section{Implications and originality}

An advantage of the rubric is that it is descriptive rather than prescriptive, giving schools an opportunity to develop their own standards. Any professional group can produce their own profile, with categories of levels and systems that reflect their own practice and development. 


\section{Introduction}

Entrepreneurship education (EE) has emerged and developed rapidly in recent years. Its focus has widened to include empowerment and transformation, encouraging young people to create their own futures (Zaho, 2012; Morris and Liguori, 2016). EE requires teachers to ensure that their teaching practice goes beyond providing knowledge (Yamakawa et al., 2016). It may require a fundamental transformation led by "fearless educators" (Vanevenhoven, 2013, p. 468), a change of culture rather than changes in technique (Rogan and Grayson 2003, p. 1200). EE requires students to be active decision-makers, and the teacher to support rather than direct them.

Educational systems across the world have engaged in extensive curriculum revision in the last half century (Thorolfsson et al., 2012). The National Curriculum in Iceland underwent revision in the late 1990s to incorporate Innovation Education (IE) into compulsory school curricula. IE is related to EE and was new to most teachers, some of whom attended IE courses offered through continuous professional training [by whom?] (Jónsdóttir and Macdonald, 2013). The term Innovation and Entrepreneurial Education (IEE) came into use, acknowledging the links between 'innovation' and 'entrepreneurship' (enterprise) in IEE, which are seen as two important aspects of learning in IEE (Jónsdóttir and Macdonald, 2013).

The core of IEE is in creative work and honing creative skills; as students grow older, the emphasis moves towards developing entrepreneurship skills and knowledge and finding a place in society (Jónsdóttir and Madonald, 2013). IEE is an overarching term for education that enhances creativity and enterprise and can emerge in many contexts, cross curricular or within subjects. This research seeks to clarify the role of the teacher in IEE with the goal of improving the quality of IEE in schools. Our research questions focus on the teachers and the school:

- What characterises the practice of six teachers working with IEE?

- What factors support teachers in developing IEE in schools?

- How can the success of the implementation and development of IEE in compulsory schools be assessed?

Data were gathered from six teachers in Iceland on their work with IEE. Innovation education in Iceland is an understudied field. This research is small scale, as it only has three schools as main sites. 
After a brief overview of some aspects of teaching IEE, the methodology is described. The development of a model which led to the main tool, a rubric, is explained, which in the rest of this article is called SERIES (social ecological rubric in innovation and entrepreneurship in school) and how it was used. Finally, the main findings are presented and discussed and some implications put forward.

\section{Teaching IEE}

IEE is emerging as a cross-curricular area that is about applying creativity and knowledge to meet needs or solve problems that students identify as important for them (Jónsdóttir and Gunnarsdóttir, 2017). It involves inventing objects and processes to improve society, and aims to develop critical and creative thinking in design, technology, marketing and enterprise. The main goals of IEE as stated in the curriculum are to enhance creativity, innovation, and the capacity to act (Ministry of Education and Culture, 2014). It emphasizes exploration, discovery and surprise, and is characterised by creativity rather than control and inspection.

\section{Creativity and agency in IEE}

IEE can be supported by engaging teachers in creative work and helping them realize the special role required to support students' creativity (Neck, 2010). Students become competent at developing ideas and actualizing them when guided by capable teachers. As children grow, the skills of being enterprising and developing entrepreneurship skills and knowledge grow too. Creativity and enterprise are integral parts of IEE, with enterprise becoming a larger component of their studies as the students age (Jónsdóttir and Macdonald, 2013). The process of implementing change or innovation interacts with aspects of teachers' beliefs about teaching and learning (Wallace and Priestley, 2011), possibly leading to a clash. One important issue in implementing IEE is acknowledging that creativity can be taught and enhanced (Neck, 2010). A constructivist approach is preferred, as it supports student agency and stresses the role of knowledge creation, as opposed to knowledge transmission (Stamp, 2016; Gunnarsdóttir, 2013).

\section{Teacher sensitivity for the creative process - artistry in teaching}

Training in various methods can help teachers to be more supportive and capable of working with students and their creative ideas (Clapham, 2003; Hosseini, 2014; Neck, 2010; Stamp, 2016). Acknowledging the emotions of students as they engage in creative processes requires sensitivity, creativity, and teacher efficacy (Cremin, et al. 2006; Jónsdóttir, 2017; Lacéus, 2014). 
Supporting the creative process requires the teacher to 'stand back' during class; to observe, listen, and notice the nature of the students' engagement (Cremin, et al., 2006; Lacéus, 2014; Paniagua and Istance, 2018).

Eisner's (2002) view of excellence in teaching is that it is considered artistic when the teacher's activity is not dominated by prescriptions or routines, but is influenced by qualities and contingencies that are unpredicted, thus finding a balance between freedom and order. Such artistry is important in IEE because teachers who function artistically in the classroom not only provide children with sources of artistic experience; they also provide a climate that welcomes exploration and risk-taking (Penaluna and Penaluna, 2009).

Enhancing creativity and action competence (enterprise) requires allowing and exercising student freedom and agency (Jónsdóttir and Macdonald, 2013; Neck, 2010). Some teachers fear losing control of classroom activities as students gain more confidence and autonomy in directing their own work (Ribeiro and Mizukami, 2005). Others think teachers have more control and coverage with everyone doing the same thing at the same time (Bernstein, 2000; Butzin, 2004). This fear of losing control has been referred to as chaos angst, which is usually unconscious and unarticulated (Jónsdóttir and Gunnarsdóttir, 2017).

\section{Professional theories and collective teacher efficacy}

Policy-makers agree that $21^{\text {st }}$ century students should be provided with general skills such as collaboration, problem framing, critical thinking, 'thinking outside of the box', innovation, and creativity (Bacigalupo, Kampylis, Punie, and Van den Brande, 2016; Hannay and Earl, 2012). In order to work with IEE in a committed and collaborative way, teachers, policymakers, and communities may need to reconsider their values, assumptions and cultures about school and education (Hannay and Earl, 2012).

IEE challenges the tacit knowledge of teachers and their general rules of practice (Hannay and Earl, 2012; Jónsdóttir and Gunnarsdóttir, 2017). Educators may need to reshape their personal and professional knowledge and mental models and learn to work creatively and together (Gudjonsdottir et al. 2007; Gralewski and Karwowsky, 2016; Levin and Nevo, 2009). Professional theories are as critical in IEE as in other areas of teaching (Darling-Hammond, 1999). Teachers make choices that are rooted in their educational philosophies and as they 
become conscious of their own values a vital step is taken (Beghetto, 2007; Craft, 2003; Dalmau and Guðjónsdóttir, 2001; Paniagua and Istance, 2018).

Professional teacher efficacy is supported by developing mastery, being emotionally moved by a task, experiencing vicarious learning, or undergoing verbal persuasion (Goddard, Hoy and Hoy, 2000). Teachers with efficacy know and trust their own ability in the classroom and enable their students to make significant gains in learning (Tschannen-Moran et al., 2014; Goddard et al., 2004). Collective teacher efficacy opens a way for teachers to become collectively competent in promoting IEE.

\section{Summary}

Several aspects of creativity and action competence are essential to the introduction of EE. A willingness to be flexible and accept unpredictability, keeping a sense of structure and stability, is important in IEE (Jónsdóttir and Gunnarsdóttir, 2017). Professional development can develop creativity skills. An emotional commitment to students and their learning makes progress possible but an unwillingness among teachers to change, take chances, or make mistakes can hinder creativity and reduce flexibility and negatively impact the learning environment (Penaluna and Penaluna, 2009).

\section{Methodology and methods}

Several approaches were used to explore patterns in the data, linking ideas and concepts with patterns and some general theories of curriculum.

\section{Understanding a curriculum in practice}

A method of assessing the introduction of a new science curriculum in South Africa through rubrics was developed by Rogan and Grayson (2003), moving from classroom to school readiness to local support. Each rubric in their case represents a construct, one for curriculum, one on conditions for change within the school and one for support for change from parties external to the school. All curriculum constructs were two dimensional, mapping expertise against components of the new curriculum, such as practical work, classroom interactions, science and society and assessment. The vertical axes progress from basic to ideal forms of practice.

When developing statements in this study for describing categories, the nature and quality of the components seemed to depend on the social and institutional context. Bronfenbrenner's (1979) 
human-ecological theory suggests a set of four nested social structures: micro-, meso-, exo- and macrosystems. It has been suggested that a fifth 'global' system is now a relevant addition to the model (Christensen, 2016). The nested systems view was used to sort the descriptive data and then ascertain whether it showed basic or further development. Thus, a model of social ecology emerged and was constructed as a rubric to demonstrate how social systems influence the practice of IEE teachers.

\section{Bronfenbrenner's concepts from socio-ecology}

Teaching is a professional activity, and personal attributes have been identified as determinants in the development of educational professionals (Lewthwaite, 2006). The individual teacher is always influenced by the surrounding social systems (Table 1). The microsystem is the innermost social system, and this is thought of as a classroom or group of students, creating a pattern of activities, roles, and interpersonal relations experienced by individuals in that setting (Bronfenbrenner 1979, p. 229). Interconnections across systems can be as decisive for development as the actions giving rise to a mesosystem, the interrelation among two or more microsystems (Table 1). Mesosystem influences are located within the school (Lewthwaite, 2006). The third system in Bronfenbrenner's ecological environment, the exosystem, refers to one or more settings that do not directly involve the teacher, but in which events occur and decisions are made that affect what happens in the setting containing the person --- such as general attitudes toward the nature of the curriculum or policy decisions at the local level (Table 1). These interconnected systems are viewed as a manifestation of underlying patterns of ideology and organization of the social institutions common to a particular culture or subculture. Within each society or subculture there exists a blueprint for the organization of every type of setting that Bronfenbrenner (1979) calls the macrosystem. 
Table 1 Framework of systems in social ecology (developed from Bronfenbrenner 1979 and Lewthwaite 2006)

\begin{tabular}{|c|c|c|c|c|c|c|}
\hline $\begin{array}{l}\text { PARTICIPATING } \\
\text { PERSONS/UNIT) }\end{array}$ & $\begin{array}{l}\text { Teacher / } \\
\text { Individual }\end{array}$ & $\begin{array}{l}\text { Immediate } \\
\text { settings } \\
\text { surrounding } \\
\text { the } \\
\text { participants }\end{array}$ & $\begin{array}{l}\text { Relationship } \\
\text { between/ } \\
\text { among } \\
\text { settings }\end{array}$ & $\begin{array}{l}\text { Events affect } \\
\text { Settings } \\
\text { concerning } \\
\text { the person }\end{array}$ & $\begin{array}{l}\text { National } \\
\text { blueprints }\end{array}$ & $\begin{array}{l}\text { Events } \\
\text { concerning } \\
\text { more than one } \\
\text { country }\end{array}$ \\
\hline $\begin{array}{l}\text { INTERACTIONS/ } \\
\text { RELATIONSHIPS }\end{array}$ & $\begin{array}{l}\text { Surrounding } \\
\text { social systems }\end{array}$ & $\begin{array}{l}\text { Pattern of } \\
\text { interaction } \\
\text { between persons } \\
\text { connected with } \\
\text { the participants }\end{array}$ & $\begin{array}{l}\text { System of } \\
\text { microsystems }\end{array}$ & $\begin{array}{l}\text { Persons not active } \\
\text { participants }\end{array}$ & $\begin{array}{l}\text { Events at a } \\
\text { national level }\end{array}$ & $\begin{array}{l}\text { Systems of macro } \\
\text { systems }\end{array}$ \\
\hline $\begin{array}{l}\text { SOURCES OF } \\
\text { INFLUENCE ON } \\
\text { THE SYSTEM }\end{array}$ & $\begin{array}{l}\text { Personal } \\
\text { Characteristics } \\
\text { of practice }\end{array}$ & $\begin{array}{l}\text { Teachers, } \\
\text { family, } \\
\text { students, } \\
\text { colleagues }\end{array}$ & $\begin{array}{l}\text { Settings, } \\
\text { timetable, } \\
\text { curriculum, } \\
\text { evaluation }\end{array}$ & $\begin{array}{l}\text { Demands of } \\
\text { modern life, } \\
\text { attitudes } \\
\text { to the nature of the } \\
\text { curriculum } \\
\text { Exo }\end{array}$ & $\begin{array}{l}\text { Government } \\
\text { policies }\end{array}$ & $\begin{array}{l}\text { Technological } \\
\text { innovations, } \\
\text { religion, } \\
\text { terrorism, } \\
\text { flux of people, } \\
\text { internet, } \\
\text { Global }\end{array}$ \\
\hline
\end{tabular}

The teacher never acts totally alone and if innovations are to be sustained it is important to look at a holistic picture. Changes aimed at enhancing student agency and creativity often require new ways of thinking about education and a different organization of learning settings. An investigation of six IEE teachers' practice in three compulsory schools (6-16 years old) was carried out. The levels of development identified within the systems gave rise to an expanded model of the "social ecology of feasible development" and three applications of the SERIES. The rationale is that the nature of IEE is such that a course of IEE will draw closely on and reflect its immediate surroundings and opportunities for innovation and entrepreneurship. It is not divorced from its surroundings, it is a part of them.

\section{Data collection}

The data underlying this research arise from interviews with teachers, students, and administrators in three schools. Three Icelandic schools known for their work with IEE were selected for participation in the research. Data collection started in autumn 2006 and finished in spring 2011. The schools are called City School, Country School, and Trio School. Teachers from all three schools attended a two-day course in innovation education prior to the study. The Data Protection Authority in Iceland was notified of the research. Permission was sought to observe lessons and to interview teachers, administrators, and students. Innovation education and general lessons were observed, and informal talks with other teachers and school staff documented. In visits to these schools, support and specialist advice and consultation were offered. 
Interviews were conducted with four IEE teachers in City School (a large school in the capital) and one in Country School (a small rural school). In Trio School (a small rural school) five individual interviews with teachers and two with the IEE lead teacher were conducted, but here the main focus is on data from the lead teacher. The interviews were aimed at eliciting a deeper understanding of factors that influence the IEE teachers' practice. Six of the teachers were asked to keep journals of their innovation teaching containing their reflections on classroom interactions. They were also asked about personal values and professional philosophies. An analysis of digital pictures taken in IEE lessons provided opportunities to see how teachers used spatial arrangements, grouping and communication. Collected data included approximately 800 pages of transcribed interviews and field notes. Law, curricula, teaching materials and descriptions from IEE teacher courses were also consulted.

City School is an urban school with around 500 students where IEE was offered for the first time in autumn 2006. Four teachers from the school attended an in-service course in August 2006. Bryndis and Anna arts teachers; Runa, a textile teacher and Heidi, a student teacher were observed and interviewed. Observations in IEE lessons were conducted from September 2006 to May 2007 with students aged 8-12. The official school policy focuses on individualized teaching and learning, and emphasizes arts and manual subjects and integrating subjects through creative projects. It has mixed-age learning groups, which is unusual for larger schools in Iceland, though common in small schools. The school is known in Iceland for its ‘open' organization.

Country School is a rural school with about 60 students (6-12 years old) and its policy is one of individualised teaching and learning. Sunny, an art teacher, was the new innovation education teacher and was also teaching carpentry for the first time. She took the same IEE course as the City School teachers. IEE lessons in Country School were observed for five weeks in spring 2007. The school has been certified as an Ecoschool and has been a leader in developing IEE in Iceland.

Trio School is a compulsory school spread across three locations in a rural area, formed in 2007 after a merger of three formerly independent small schools. IEE in Trio School was led by Sif, a teacher who attended the same IEE course as the teachers in the other schools. A basic course on IEE in Trio School was held, with a majority of teachers - but not administrators -- attending. In November 2007 a follow-up course for the group of IEE teachers was offered, and collaboration 
and research started at the same time. The last course was in February 2009, when additional data were gathered. Students in Trio School taking part in IEE were aged 6-16.

In all three schools, innovation teachers were interviewed individually, and in City School and Trio School as a focus group as well. Data from lessons were collected from all three schools. The teachers sometimes asked for advice from the researcher when needed, as had been agreed with the principals. The principals were also interviewed. Groups of students 8-12 years old were interviewed in City and Trio Schools. Interviews were recorded and transcribed by a professional transcriber.

\section{Developing the ecological model through the analysis}

Qualitative methods were deployed in data gathering and analysis, including open coding and discourse and image analysis (Bogdan and Biklen, 2003). Constant comparison was used (Creswell, 2003; Cohen et al. 2005, p. 151); data were analysed as soon as they had been gathered, and matters of interest were pursued in the next gathering of data. Observations were first noted in a notebook and photographs taken on location. After each visit interviews were transcribed and observation notes expanded into a more thorough description in a Word document with pictures related to the description. At the end of each such manuscript, notes and questions were added, with initial thoughts and interesting leads to follow up in the next visit. Data from law, curricula and descriptions of IEE teacher courses were regularly consulted to sharpen the focus in the next visits. Initially this inductive approach led data gathering and analysis, but gradually theories and models became influential, providing deductive lenses for more complex analysis.

The approach allowed an in-depth study of subjects, events and activities in a school context and accounts of the perspectives of the participants involved (Bogdan and Biklen, 2003; Creswell, 2003). IEE is highly contextual, and can therefore be presented differently in different settings. Applying the SERIES rubric to the data helped to locate levels of development in IEE and to find the ways in which teachers contextualised and interpreted IEE.

\section{Constructing the data-led rubric}

The extensive data from the field work and other recorded data (e.g. law, teacher courses and curricula) was matched with the systems, item by item, and patterns began to emerge across several settings. By looking at the data through a social ecology lens, aspects of feasible IEE 
development started to emerge, sometimes positively and sometimes by default. Eventually the more detailed pattern was visible, and the data could be organised into systems according to Bronfenbrenner, including possible levels of development for each person from basic to ideal. In essence, the outcome provides a model of a holistic view of a social ecology in education, transformed into a rubric. To design the rubric, the theory was essential; to test the rubric, data from the field was necessary. The idea of gradual development from Rogan and Grayson (2003) was important to show feasible movement between levels (Table 2).

In order to locate school and individual development, basic descriptions start at level 1 in each system. The rubric can also be read horizontally to look for connections or interactions across the different systems (Table 2). Personal factors (affecting teachers), the school organisation (microsystem), school ethos (mesosystem), relationship with local communities (exosystem) and Icelandic society (macrosystem) should preferably be at similar levels in order to sustain development. If categories develop concurrently, they can support each other.

\section{Ethical issues}

The main ethical concern in this research was that participants should not be harmed by their participation. To meet that requirement names of persons and schools are pseudonyms. Participants were informed verbally and in writing about the study and participation was voluntary. Written consent was obtained from participants and parents and all had the opportunity to withdraw from the study at any time and nobody withdrew. The main participants read the findings about their schools and were asked to comment or if they wanted anything changed.

The first author had taught IEE in primary school and had positive views towards the subject. The researcher made these views clear from the outset and the second author monitored keeping objective distance between data and interpretation.

\section{Limitations}

General views in society -- particularly those of parents -- towards innovation education need to be more clearly identified and voiced than was possible in this research. It would also be interesting to see an additional column within the microsystem displaying students development to an ideal level. 


\section{Findings: Locating IEE teachers and schools within the SERIES}

There is variation across schools in that the six teachers displayed different characteristics of IEE practice in developing towards an ideal level. The differences are seen when comparing rubrics displaying the features of a social ecology of a feasible IEE development (Table 2). The rubric records systems and levels, from basic to ideal, in the development of teachers' practice and schools in implementing IEE. The first column displays characteristics of development towards ideal IEE teaching found in the data. Lower levels are subsumed into higher ones. However, there are teachers, schools and systems that might not display any of the practices or attitudes named in level 1 because their practice would be so rudimentary that it is off the map.

The mapping feature enables focusing on feasible and preferred curricular features that could be enhanced either by support within systems or by interaction of the different systems, emphasizing how the systems influence the role of the IEE teacher. 
Table 2 A model of SERIES (social ecological rubrics of innovation and entrepreneurship in school)

\begin{tabular}{|c|c|c|c|c|c|}
\hline 4 Ideal & $\begin{array}{l}\text { Teacher supports autonomous } \\
\text { work, learner initiative, learner } \\
\text { activity -and learner responsibility. } \\
\text { Confident teaching efficacy; skillfu } \\
\text { IEE pedagogical content and } \\
\text { curriculum knowledge. Creates } \\
\text { links and connection to parents and } \\
\text { society. }\end{array}$ & $\begin{array}{l}\text { Leaders acknowledge importance } \\
\text { of IEE. Support with timetabling; } \\
\text { highlight IEE in school curricula, } \\
\text { support fiscal needs. School } \\
\text { supports autonomous work and } \\
\text { learner responsibility. Active } \\
\text { participation of colleagues in IEE. } \\
\text { Actively introducing IEE work to } \\
\text { society. }\end{array}$ & \begin{tabular}{|l|} 
A priority placed on IEE as a \\
curriculum area by school. Location \\
and space for IEE lessons \\
supportive. Good, rational \\
connections with other school \\
work. Ample space, tools and \\
materials.
\end{tabular} & $\begin{array}{l}\text { The community expects and } \\
\text { supports innovation education. } \\
\text { Parents acknowledge importance of } \\
\text { IEE as an integral part of } \\
\text { schoolwork. Different methods of } \\
\text { quality as sessment equally } \\
\text { important in the public eye. }\end{array}$ & $\begin{array}{l}\text { Developmental agendas include } \\
\text { support for IEE development. } \\
\text { Evaluation and assessment } \\
\text { procedures acknowledge process } \\
\text { and creativity. Official discourse } \\
\text { about innovation and creativity is } \\
\text { directed towards education on all } \\
\text { levels. }\end{array}$ \\
\hline 3 & \begin{tabular}{|l|} 
Teacher supports taking risks, \\
experiments and folly. Shared \\
responsibility with \\
learners. Balances control and \\
freedom skillfully. Pedagogical IEP \\
knowledge.
\end{tabular} & $\begin{array}{l}\text { Leaders actively familiar with IEE. } \\
\text { Support of school community } \\
\text { towards IEE. Colleagues support } \\
\text { IEE. Leaders mediate external } \\
\text { support. }\end{array}$ & $\begin{array}{l}\text { Evaluation procedures in school } \\
\text { include process and creativity. } \\
\text { Timetable supportive of project } \\
\text { work. School positively receptive to } \\
\text { learning and change. School } \\
\text { emphasis on arts and manual } \\
\text { subjects. }\end{array}$ & $\begin{array}{l}\text { Parents interested and supportive } \\
\text { towards IEE. Creativity and } \\
\text { innovation seen as essential } \\
\text { elements of learning. Process } \\
\text { measures of school quality } \\
\text { acknowledged. }\end{array}$ & $\begin{array}{l}\text { Teacher education includes IEE - } \\
\text { harmony between teacher education } \\
\text { and official innovation } \\
\text { discourse. Official mandates } \\
\text { acknowledge the complexity of } \\
\text { deep changes and pay scale } \\
\text { structures promote professional } \\
\text { development. }\end{array}$ \\
\hline 2 & \begin{tabular}{|l|} 
Teacher acknowledges learner \\
ideas, supports initiative. \\
Constructivist views. Artistic \\
orientation towards teaching; \\
supports learner creativity. Creates \\
a relaxed atmosphere.
\end{tabular} & $\begin{array}{l}\text { Leaders familiar with IEE } \\
\text { pedagogy. Allow IEE as a part of } \\
\text { school practice (curriculum). Allow } \\
\text { external support. Colleagues know } \\
\text { about IEE. }\end{array}$ & $\begin{array}{l}\text { An emphasis on or opening spaces } \\
\text { for integrating subjects in creative } \\
\text { projects. IEE lessons within main } \\
\text { building. IEE a part of the } \\
\text { developmental agenda. }\end{array}$ & $\begin{array}{l}\text { Parents are informed and take part } \\
\text { in IEE. IEE seen to support } \\
\text { traditional subjects. }\end{array}$ & $\begin{array}{l}\text { Law and policy expect innovation } \\
\text { education. National curriculum } \\
\text { includes innovation education. }\end{array}$ \\
\hline \multirow[t]{2}{*}{1} & $\begin{array}{l}\text { Teacher interested in IEE. Learners } \\
\text { have partial choice. Limited } \\
\text { flexibility and chaos angst. }\end{array}$ & $\begin{array}{l}\text { School leaders neutral but allow } \\
\text { teacher initiative. IEE as } \\
\text { 'attachment'. Colleagues } \\
\text { indifferent. }\end{array}$ & $\begin{array}{l}\text { IEE lessons an isolated undertaking } \\
\text { within school. }\end{array}$ & $\begin{array}{l}\text { General views in the local society } \\
\text { neutral towards IEE. Parents' } \\
\text { involvement minimal. Traditional } \\
\text { subjects, main reference for school } \\
\text { quality. }\end{array}$ & $\begin{array}{l}\text { Law and policy allow innovation } \\
\text { education. Official discourses } \\
\text { expect innovation in society. }\end{array}$ \\
\hline & $\begin{array}{c}\text { Personal factors } \\
\text { Characteristics of practice }\end{array}$ & Microsystem factors & Mesosystem factors & Exosystem factors & Macrosystem factors \\
\hline
\end{tabular}


In analysing the characteristics of the teachers' practice and mapping results into the SERIES model, the teachers and schools in this study were found to be at different levels in the systems, as presented in Table 3.

Table 3 Location of IEE with teachers in three schools and in surrounding systems

\begin{tabular}{|c|c|c|c|c|c|}
\hline \multicolumn{6}{|c|}{ Trio school - teacher and surrounding systems } \\
\hline 4 Ideal & & & & & \\
\hline & Sif lead teacher TS & & & & \\
\hline 3 & & & Trio School starting & & \\
\hline 2 & & Trio School & Trio School & Trio School & Icelandic society \\
\hline 1 Basic & & & & & \\
\hline $\begin{array}{c}\text { levels } \\
\text { Systems } \rightarrow\end{array}$ & Personal factors & Microsystem & Mesosystem & Exosystem & Macrosystem \\
\hline \multicolumn{6}{|c|}{ City school - teachers and surrounding systems } \\
\hline 4 Ideal & & & & & \\
\hline 3 & $\begin{array}{l}\text { Runa, Bryndis and } \\
\text { Anna }\end{array}$ & & City school & & \\
\hline 2 & Heidi & City school & & & Icelandic society \\
\hline 1 Basic & & & & City School & \\
\hline $\begin{array}{c}\text { levels } \\
\text { Systems } \rightarrow\end{array}$ & Personal factors & Microsystem & Mesosystem & Exosystem & Macrosystem \\
\hline \multicolumn{6}{|c|}{ Country School - teacher and surrounding systems } \\
\hline 4 Ideal & & & & & \\
\hline 3 & & & & & \\
\hline 2 & Sunny & $\begin{array}{l}\text { Country School } \\
\text { starting }\end{array}$ & & & Icelandic society \\
\hline 1 Basic & & Country School & Country School & Country School & \\
\hline $\begin{array}{c}\text { levels } \\
\text { Systems } \rightarrow\end{array}$ & Personal factors & Microsystem & Mesosystem & Exosystem & Macrosystem \\
\hline
\end{tabular}


Table 3 Location of IEE with teachers in three schools and in surrounding systems

The research questions call for a close understanding of the personal and professional role of the teacher, what facilitates SERIES at the classroom or school level in the setting in which the teacher works, and the more remote systems influencing their practice directly or indirectly.

\section{Personal and professional factors}

All teachers in the three schools showed readiness to allow students some autonomy and choice in the IEE lessons. They were also mostly positive about student ideas and were developing lessons towards increasing student autonomy. All IEE teachers in City School, Sunny in Country School, and most of Trio School's teachers said that they wanted their teaching to be exciting and creative; they realized the need to build on structures that allowed freedom and creativity, and showed a willingness to try new approaches and take risks in their teaching. Three of the teachers in City School, Anna, Runa and Bryndis seemed confident in taking risks, trying new things, using new materials and acting spontaneously as they went along, thus displaying artistry in teaching. Runa acknowledged the need for structure and that students needed to learn how to use tools and methods but that she tended to prefer freedom to strict structure. Students themselves did not always have much experience of freedom to make their own decisions. Runa realised that it took students time to accept the agency offered in the IEE lessons:

It seemed that in the beginning they were constantly asking, 'can I do it like this' and I would answer 'yes if you like' and it took them a while to realize that they were in control and gradually they started to say 'I am going to do this ', it seemed to have developed quite a bit.

All teachers in Trio School were required to take part in teaching IEE for one week in collaboration with other teachers in the school. Some were reluctant to try IEE in the first place, and were not willing to take risks in their own teaching. There were some differences in how the teachers handled matters when students wanted to play with the freedom they were offered. Sif the lead teacher understood the challenge for some of her colleagues:

Teachers are very tenacious about their territory. They are used to controlling and teaching and that is one of the things they partially have to get rid of when they take on IEE, to no longer control but rather guide, be there and help out. Not to give their own opinion but rather elicit the students' opinion. It is a bit difficult to get the teachers into 
this particular channel. Some of them have taught for many years and they are deep in their rut; they have a fixed mindset.

The four teachers in City School, Sunny in Country School, and Sif in Trio School showed signs of a constructivist approach to teaching through the mind maps they drew of themselves and in the interviews. Sunny in Country School said she wanted to offer meaningful activities where students get to explore, experiment and create:

I want to give my students a chance to work where they are not hovering over books all the time. Rather I want to trust them to do a certain job, they create their own things. They get an opportunity to design and innovate and sort things out.

Sunny in Country School and Heidi in City School appeared to have mostly moved on to level 2 as IEE professionals. They still leaned towards strong control over the students' actions and decisions. These two teachers tended to take control and decide for students, setting more limits to what was allowed, and thus may still be partially located on level 1. Runa, Anna and Bryndis at City School seemed to have mastered the art of allowing the students to experiment (level 3) while maintaining a level of control that did not stifle creativity. Responsibility for the work of the students was shared. The teachers knew when to 'stand back' when students were developing their ideas and responded to their questions openly rather than with 'right' answers. Sif, the lead teacher in Trio School, appeared to be on levels 3 and 4, supporting students' initiative and activities, confident in IEE pedagogical knowledge and with several links between the school and the community in the IEE projects.

\section{Microsystem - patterns of roles and support}

The microsystems in Country and Trio School -- including the pattern of activities, roles, support and views of colleagues -- were at similar levels (2), with some differences. In Country School, IEE activities were supported as a one-teacher task, and the view of the school leader was neutral, allowing innovation education to take place but not making an effort to draw other teachers into the work. In Trio School, a collaborative group of teachers had been created initiated by the lead teacher and supported by the principal, showing collective teacher efficacy but with some teacher reservations. In City School, middle management actively took part in developing IEE and had explicit support from the principal (level 2). 
In all three schools the principals allowed a specialist to provide external support. The lead teacher at Trio School emphasised the importance of the support they received from the specialist's visits. The microsystem of City School has thus moved toward level 3, although the school community as a whole is not actively involved. To move forward in developing IEE, the schools and teachers could be looking for ways to support more teachers, which could move personal-professional development to level 3 and the microsystem to at least level 3.

\section{Mesosystem - priorities and arrangements in the school}

The mesosystem around IEE within a school shows its level of awareness, priorities and arrangements. The mesosystem at City School was supportive of IEE, showing characteristics of level 3 because of its emphasis in words and actions, such as emphasis on project work, integrating subjects, manual subjects and the arts and assessment that values creativity and process. IEE is also on the developmental agenda of City School, where the whole atmosphere is linked to school-wide development. There was even some tiredness in the staff, as every teacher actively took part in some kind of developmental work. The school could promote IEE, making it more visible and important as a curriculum area, increasing the connections to other school work. It could involve the whole school community and make facilities more supportive to IEE by supplying more storage space, tools and accessible organization of materials. These actions are intertwined with the microsystem and are logically interdependent.

In Country School, innovation education has depended on one individual for many years. This school is mainly at level 1 , although the visibility of IEE locates it partially at level 2 . A school policy of enhancing creativity and manual subjects, integrating subjects in project work and giving more value to process evaluation would prepare entering level 3.

In all three schools the ambition to do good work was apparent in the attitudes of leaders and teachers and appeared in participation in different developmental projects, one indicator being their aspiration to try IEE.

\section{Exosystem - views and connections to society - invisible barriers}

Characteristics of the exosystem indicate that IEE implementation is low in Country and City School, but at level 3 for Trio School. Community views towards innovation education are neutral in City School and Country School, as there was little or no parental involvement $=($ level 1). The micro- and mesosystems are where the school staff could use opportunities to talk about 
IEE with parents, show examples of IEE work and offer convincing evaluation of the work in IEE. In Trio School, by contrast, there was active collaboration in IEE work with the community. This connection is a strength for IEE and can help to develop it further and sustain its existence in the Trio School curriculum. Trio School had been presenting IEE to locals and doing outreach programs such as running a coffee house and working with local industry, where the public and worklife welcomed the schools (level 2). As in other countries, a greater respect for academic subjects over creative arts and manual school subjects gives esteem to traditional learning (Goodson, 1993; Paecther, 2000); this bias permeates local and remote attitudes.

Interactions between the exosystem and the other systems seem to be limited. The next feasible step for developing IEE is keeping parents and members of society informed and interested in IEE, and convincing them that it supports traditional subjects. Eventually, they would accept the intrinsic value of IEE, not just what it offers other subjects. That must be the joint task of the individuals in the schools, the micro- and mesosystem; it also calls for support from the macrosystem. Only Trio School seems to have moved beyond level 1 in this regard.

\section{Macrosystem - the blueprint for schools and teachers}

The macrosystem interacts with and affects all the other systems. The national curricula in 1999 for both compulsory schools and upper secondary schools included chapters about innovation and entrepreneurship education. There is, however, no official action plan for the development of innovation education in schools or in teacher education. Evaluation also plays a crucial role in deciding what students learn and what teachers teach in schools (Agrawa,1 2004; Eisner, 2002). None of the official assessment procedures in Iceland in prioritize process and creativity. The working conditions of teachers and of working parents are determined through national agreements and have repercussions for school staff and family life. In City School the teachers were enthusiastic in their work, but tired. It was clear from their informal conversations that tackling change as well as matters of family and home was tough. Development work is squeezed into overfull schedules. The Icelandic macrosystem showed signs of development at level 2 with regard to IEE with compulsory school law expecting innovation and enterprise.

\section{Moving on - potential development}

To move on with feasible actions in Country School might require finding ways of mediating external support which could involve school leaders and other colleagues more in the 
development of IEE, strengthening both personal factors and the microsystem. The interaction between the individual and microsystem is important. IEE teachers may develop to higher levels within a neutral microsystem, but their development is enhanced by a leader's active support and colleagues' involvement. City School could make the whole school community more involved, making IEE clearly visible in the formal curricula and highlighting and introducing IEE actively to society, thus influencing the exosystem as well as gaining support for the teachers' work. Trio School could work through the tensions of different views of teachers and use reflective evaluation of the IEE development in the school. After experiencing the strengths of working with IEE, some of the teachers in Trio School had been expanding these ways of working to other subjects, showing signs of gradual progression and growing collective teacher efficacy in IEE within the school.

\section{Discussion: Supporting teachers and driving development}

The role of the efficient IEE teacher is a role that a competent professional can master. It involves as finding a balance between structure and freedom in teaching and learning in order to support creativity and action competence. In this stody, social influences from the different systems were identified and an outline of progress of teachers and schools emerged. Visions in the curricula and teaching materials from the IEE pioneers were used to construct descriptive progression indicating the levels within the social ecology of feasible development. In this way it was possible to fill in the rubric with indicators (descriptive text) and at the same time locate the level of implementation of IEE for teachers and schools and the feasible levels for development.

Several factors may support or restrict the IEE teachers' efficacy in social systems within the school and beyond. A model of the social ecology of feasible development was constructed in the form of the SERIES (Social ecology rubric for innovation and entrepreneurship in schools) and used to analyze the data in this research. Systemic interaction was identified in the progression of innovation and_entrepreneurial education_from one level to another. Scrutinizing these interactions or their absence can inform the teachers' praxis and determine potential paths for further development.

\section{Teaching IEE - personal and professional}

The six innovation education teachers were at different levels of IEE development corresponding to their training and their personal and professional inclinations. Teachers vary in the kinds of 
support they need. Identifying these needs and reckoning with teachers ' professional and personal orientations is fundamental to the journey to innovation. Having an artistic orientation seems to help some teachers deal with the balance needed between freedom and structure in the classroom, where teachers seek to give value to student voices, elicit the tacit knowledge of students, and promote situated learning. The capacity of the teachers to stand back, allow enough freedom, accepting the role of the 'flexible teacher' in order to enhance student agency and creativity within reasonable boundaries and within different contexts, seems to make the greatest difference in realising the potential of IEE (Cremin, et al., 2006; Jónsdóttir and Gunnarsdóttir, 2017; Neck, 2010; Stamp, 2016).

\section{Strengthening professional efficacy - microsystem}

Teacher efficacy development towards the 'ideal' innovation teacher may depend on teachers being more conscious of their own ways of teaching (Gudjonsdottir, et al. 2007), balancing freedom and structure and also towards seeing connections with society as a normal part of their work. This awareness helps teachers offer freedom of different elements in lessons such as choice of ideas to work on, development of ideas, when to finish tasks, choice of methods and materials and location of work (Jónsdóttir, 2017). A part of potential freedom is making the criteria of evaluation visible, as this can influence not just what is expected of students in IEE but also make clear to the public, especially parents, what is gained with such learning. Criteria of evaluation must be carefully chosen so that they do not display only what behavior is wanted, but also what kind of skills are valued.

\section{Expectations within the microsystem}

What is expected of teachers within the microsysem and how that fits with their teaching philosophies does matter, and needs to be understood by each and every teacher (DarlingHammond, 1999; Gudjonsdottir et al. 2007). Changing teachers' educational beliefs is a process that can take considerable time, and the change process is often charaterised by a mosaic of different paradigms (Levin and Nevo, 2009). Supporting teachers in making their educational philosophies visible and facing possible ,chaos angst ${ }^{\star}$ can be supported by actions within the micro and mesosystems, within the schools, by arranging for time and specialist support. These steps would be influenced in turn by actions within the exosystem and macrosystem that indicate the kind of knowledge and skills that are considered important, along with supportive working conditions. It seems that individual teachers can move to a relatively high level. Sustaining and 
increasing that level, however, seems unlikely without progression within the neighboring and more remote systems.

\section{Operations management - mesosystem}

Differences were detected in the views of teachers. school ethos, policy, and the construction of the school curriculum and timetabling decisions. A hindrance for some teachers and schools is the interdisciplinary nature of IEE, which is a challenge to the segmented organisation of schools in general. City School, with its policy of crossing boundaries of subjects and age groups, was more accommodating to IEE than the other two schools. They had a team of innovation education teachers that made up the communal cluster (Shulman and Shulman, 2004) -- or the collective teacher efficacy (Tschannen-Moran, et al., 2014) necessary for development. However, the cluster members need to expand and distribute their acquired expertise within the school in order to sustain the collective efficacy for teaching IEE. Moreover, dedicated and enthusiastic teachers are not enough to balance the increased workload of reacting to change demands without risking exhaustion (Ballet and Kelchtermans, 2008). Such demands refer to the macrosystem as well, where the working conditions of teachers and of working parents are determined.

\section{Working together, schools and communities - exosystem}

The current interaction between the exo- and other systems in these examples is weakest in City and Country School, as the parents and the local communities are not active participants in IEE and the other systems are not soliciting their input. One way to make an impression on parents and local policymakers is to discuss the value of this kind of education, making it more visible, as Trio School has done. A general introduction to IEE and its potential could be offered to parents and the local society, preferably with the active participation of students. Assessment of the quality of education is important to parents, and therefore other forms of evaluation are more appropriate for innovation education than traditional tests must be presented.

\section{Support at the macrosystem level}

The macrosystem, the underlying culture in the country, seemed somewhat supportive of the new curriculum area IEE. Visible in the Icelandic macrosystem is increasing evidence of global policies such as the policy for the year of 2009 for Innovation and Creativity (European Union, 2008) and the policy of the UN with regard to the Decade of Education for Sustainable 
Development 2005-2014 (UNESCO, 2003). Such external policies put pressure on the Icelandic macrosystem to deliver the kind of creative and integrating education of which IEE is an example. However, the change required of teachers to work in the way IEE entails is currently not decisively supported within the macrosystem in Iceland.

The feasible steps for the macrosystem, the policy makers, would be a focus on the exosystem and a survey of societal views, and could include a dedicated policy for IEE and credible information of the potential of IEE for learning and evaluation procedures which teachers could use. At the same time the macro context of teachers' pay scales and general contract may be in need of revision to reflect continuous and daily development in the demanding work of teaching. If there is to be harmony between teacher education in Iceland and the official innovation discourse, there needs to be a substantive offer of training for student teachers in IEE that is not now available.

SERIES - Looking at the whole social ecology of IEE

The SERIES rubric designed in this research process offers a descriptive map of a feasible social ecology for development of the IEE teacher and the interacting systems that influence each other in conducive or restrictive ways depending on their levels of development. The rubric shows that educational development is made up of multiple and complex systems, and that the steps to be taken between levels are dynamic. The feasibility of a next step often depends not just on taking the step itself, but on the level of development of the surrounding systems. SERIES shows these connections and interactions as a holistic model.

\section{Conclusions and implications}

To enhance the innovative and creative capacity of people through education, help them imagine possible futures and guide them in choosing their preferred option, skilled teachers are needed who can master the art of balancing freedom versus order. But the teacher is not an island; he or she is always a part of a set of social systems.

\section{For policy makers, research and practice}

Policy makers now have an opportunity to understand that no matter how appropriate or relevant changes in education seem to be, they will not take root without implementation strategies that take into account both the local context and personal factors, as well as less visible and more remote factors that influence each other in complex ways. The changes IEE requires contradict 
many of the prevailing structures of schools that are the result of their history. They also clash with the general views in society about what 'real' school is like. These factors can inhibit teachers from developing to the ideal level of the educational innovation in question.

The SERIES model constructed through the analysis in this research offers a descriptive rubric to identify the current and feasible levels of development of teachers' work in curricular innovations, including effects of interacting systems, thus allowing a coherent picture of a specific educational area to emerge in suitable detail. A range of social and institutional influences on the work of teachers can be identified using the SERIES model. Using the model on the data helped to make visible the influences and opportunities of teachers working with IEE in three Icelandic schools and their local and remote environments. It seems that the change of the role of the teacher from the 'traditional' to the 'flexible' teacher is one of those 'deep' changes rooted in the various social ecologies that require a collective effort. The culture that teachers work within enhances or hinders their further development; and the policy (or lack thereof) and views of macro- and exosystems play a part in changing that culture.

The interaction between the macro- and exosystems is sometimes obscure, but it is possible and helpful to analyse the exosystem separately to identify and remove barriers formed by outmoded views of what is relevant education. Trio School's exosystem is a testament to interaction between school activities and the community. Further research of the influence of the exosystem, i.e. parents' views and policy in that locality, could be revealing and helpful in taking steps to enhance IEE in Iceland.

Teachers and schools can develop without support from the exo- and macrosystems, but the development is fragile and likely to waver in the absence of support from neighbouring systems. Top-down forces at the national and local levels could increase the influence of their mandates by addressing the complicated interaction needed for change, and developing appropriate support. The interactions between systems are crucial to developing a social ecology of feasible development. Any school can be mapped in a rubric of social ecology, but the actual levels cannot be fixed until there is enough data to elicit the descriptions for each system and the level.

Rogan and Grayson's and Bronfenbrenner's theories were used to develop a practical tool to analyse the developmental level of teachers and different settings in innovation and entrepreneurial education. Having theoretical tools that work in practice and creating access to 
information for understanding interactions might help schools to make decisions that sustain what has been achieved and support further development. Policy makers implementing educational innovations need to consider the local context, the diversity within each context, and the psychological factors that can support learning and change. The main outcome of this research is a model in the form of a rubric, that can be used in other edcuational research and as a practical tool in schools. An advantage of the rubric is that it is descriptive rather than prescriptive, giving schools an opportunity to develop their own standards. The model is applicable to other curricular innovations and can be adapted to different topics and other contexts, revealing active or potential contributors in underlying systems supporting deliberate actions towards the ideal situation.

A special wish

A final point is that it would be useful if IEE combined forces with sustainable education. Various forms of socio-ecological systems would benefit from an association with sustainability and IEE. Being able to practice innovation education successfully and linking it to sustainability would open up ways of understanding some of our wicked problems. Addressing wicked problems and responding to needs with creativity and action copmetence would make a good fit, for example. A criterion or step relevant to sustainability could be added to the design cycle.

\section{References}

Adams, C.M. and Forsyth, P.B. (2006), "Proximate sources of collective teacher efficacy", Journal of Educational Administration, Vol. 44 No. 6, pp. 625-642.

Bacigalupo, M., Kampylis, P., Punie, Y., and Van den Brande, G. (2016), EntreComp: The Entrepreneurship Competence Framework, No. EUR 27939 EN, Luxembourg, Publication Office of the European Union.

Ballet, K., and Kelchtermans, G. (2008), "Workload and willingness to change: disentangling the experience of intensification”, Journal of Curriculum Studies, Vol. 40, No 1, pp. 47-67.

Beghetto, R. A. (2007), "Does creativity have a place in classroom discussions? Prospective teachers' response preferences", Thinking Skills and Creativity, Vol. 2, No. 1, pp. 1-9. doi: 10.1016/j.tsc.2006.09.002

Bell, B., and Gilbert, J. (1994), "Teacher development as professional personal and social development", Teaching and Teacher Education, Vol. 10 No. 5, pp. 483-497.

Bronfenbrenner, U. (1979), The Ecology of Human Development, Cambridge, MA, Harvard University Press. 
Bernstein, B. (2000), Pedagogy, Symbolic Control and Identity, $2^{\text {nd }}$ ed., Lanham, Rowman \& Littlefield Publishers, INC.

Butzin, S. M. (2004), "Project CHILD: A proven model for the integration of computer and curriculum in the elementary classroom", Asia-Pacific Cybereducation Journal. Vol.1 No.1 pp. $0-0$.

Christensen, J. (2016), "A critical reflection of Bronfenbrenner's development ecology model", Problems of Education in the 21st Century, Vol. 16, pp. 22-28. ISSN 1822-7864.fglobal

Clapham, M. M. (2003), "The development of innovative ideas through creativity training”, in L. V. Shavinina (Ed.), The International Handbook on Innovation, Amsterdam, Elsevier Science, pp. 366-376.

Cohen, L., Manion, L., and Morrison, K. (2005), Research Methods in Education, 5. ed., London, RoutledgeFalmer.

Craft, A. (2003), "The limits to creativity in education: dilemmas for the education", British Journal of Educational Studies, Vol. 51 No. 2, pp. 113-127.

Craft, A. (2006), “'Little c Creativity'”, in A. Craft, B. Jeffrey and M. Leibling (Eds), Creativity in Education, London, Continuum, pp. 45-61.

Cremin, T., Burnard, P., and Craft, A. (2006), "Pedagogy and possibility thinking in the early years", Thinking Skills and Creativity, Vol. 1 No. 2, pp. 108-119.

Creswell, J. W. (2003), Research Design. Qualitative, Quantitative, and Mixed Methods Approaches, Thousand Oaks, Sage Publications.

Dalmau, M. C., and Guðjónsdóttir, H. (2002), "Framing professional discourse with teachers: Professional working theory", in Loughran, J. and Russell ,T. (Eds.), Improving Teacher Education Practices Through Self-study, London, RoutledgeFalmer, pp. 102-129.

Darling-Hammond, L. (1999), Doing What Matters Most: Investing in Quality Teaching. New York, National Commission on Teaching and America's Future.

Eisner, E. W. (2002), The Educational Imagination. On the Design and Evaluation of School Programs, New York, Macmillan.

European Union (2008), "Decision No 1350/2008/EC of the European Parlaiment and of the Council of 16 December 2008 concerning the European Year of Creativity and Innovation (2009)", Official Journal of the European Union, 348/115-348/117.

Fullan, M. (2001), Leading in a Culture of Change, San Francisco, Jossey-Bass.

Goddard, R.D., Hoy, W.K. and Hoy, A. W. (2004), "Collective efficacy beliefs: Theoretical developments, empirical evidence, and future directions", Educational Researcher, Vol. 33 No. 3, pp. 3-13. https://doi.org/10.3102/0013189X033003003

Goodson, I. F. (1993), School Subjects and Curriculum Change. Studies in Curriculum History, 3rd. Ed., London, The Falmer Press.

Gralewski, J., and Karwowsky, M. (2016) "Are teachers' implicit theories of creativity related to the recognition of their students' creativity?", Journal of Creative Behavior, Vol. 52 No. 2, pp. 156-167. 
Gudjonsdottir, H., Cacciattolo, M., Dakich, E., Davies, A. C., Kelly, C., and Dalmau, M. C. (2007), "Transformative pathways: Inclusive pedagogies in teacher education", Journal of Research on Technology in Education, Vol. 40 No. 2, pp. 165-182.

Gunnarsdóttir, R. (2013). "Innovation education: Defining the phenomenon", in L. V. Shavinina (Ed.), The Routledge International Handbook of Innovation Education, London, Routledge, pp. $17-28$.

Hannay, L., and Earl, L. (2012), "School districts triggers for reconstructing professional knowledge", Journal of Educational Change, Vol. 13 No. 3, pp. 311-326.

https://doi.org/10.1007/s10833-012-9185-2

Hosseini, A.S. (2014), "Survey the influence of the creativity teaching model on teachers' knowledge, attitude, and teaching skills", International Journal of Sociology of Education, Vol. 3 No. 2, No. 106-117. doi:10.4471/rise.2014.08

Johnson, E. (2008), "Ecological systems and complexity theory: Toward an alternative model of accountability in education", An International Journal of Complexity and Education, Vol. 5 No. 1, pp. 1-10.

Jónsdóttir, S. R. (2017), "Narratives of creativity: How eight teachers on four school levels integrate creativity into teaching and learning", Thinking Skills and Creativity, Vol. 24, No. 1, pp. 127-139.

Jónsdóttir, S. R., and Gunnarsdóttir, R. (2017), The Road to Independence: Emancipatory Pedagogy, Rotterdam, Sense.

Jónsdóttir, S. R., and Macdonald, A. (2013), "Settings and pedagogy in innovation education", in L. V. Shavinina (Ed.), The Routledge International Handbook of Innovation Education, London, Routledge, pp. 273-287.

Lacéus, M. (2014), "An emotion based approach to assessing entrepreneurial education", The International Journal of Management Education, ISSN: 1472-8117, Vol. 12, No. 3, pp. 374-396. Doi: https://doi.org/10.1016/j.ijme.2014.06.005

Levin, T., and Nevo, Y. (2009), "Exploring teachers' views on learning and teaching in the context of a trans-disciplinary curriculum", Journal of Curriculum Studies, Vol. 41 No. 4, pp. 439-465.

Lewthwaite, B. (2006), "Constraints and contributors to becoming a science teacher-leader", Science Education, Vol. 90 No. 2, pp. 331-347.

Ministry of Education and Culture (2014), The Icelandic National Curriculum Guide for Compulsory Schools - with Subject Areas, Reykjavík, author. Retrieved from https://www.government.is/library/01-Ministries/Ministry-of-

Education/Curriculum/adalnrsk_greinask_ens_2014.pdf

Morris, M. H. and Liguori, E. W. (2016), "Teaching reason and the unreasonable. In: Morris, M. H., Ligouri, E. (Eds), Annals of Entrepreneurship Education and Pedagogy, Northampton: Edward Elgar Publishing, pp. xiv-xxii.

Neck, H. M. (2010), "Idea generation", in W. D. Bygrave and A. Zacharakis (Eds.), The Portable MBA in Entrepreneurship, Hoboken, N.J., Wiley, pp. 27-52.

Paecther, C. (2000), Changing School Subjects: Power, Gender and Curriculm, Buckingham, Open University Press. 
Paniagua, A. and D. Istance (2018), Teachers as Designers of Learning Environments: The Importance of Innovative Pedagogies, Educational Research and Innovation, OECD Publishing, Paris, https://doi.org/10.1787/9789264085374-en

Penaluna, A. and Penaluna, K .(2009), "Assessing creativity: drawing from the experience of the UK's creative design educators", Education + Training, Vol. 51 No. 8/9, pp.718-732, https://doi.org/10.1108/00400910911005262

Ribeiro, L. R. d. C., and Mizukami, M. d. G. (2005), “An experiment with PBL in higher education as appraised by the teacher and students", Interface - Comunic, Saúde, Educ, Vol. 9 No. 17, pp. 357-368.

Rogan, J. M., and Grayson, D. J. (2003), "Towards a theory of curriculum implementation with particular reference to science education in developing countries", International Journal of Science Education, Vol. 25 No. 10, pp. 1171-1204.

Shulman, L. S., and Shulman, J. H. (2004), "How and what teachers learn: a shifting perspective", Journal of Curriculum Studies, Vol. 36 No. 2, pp. 257-271.

Stamp, J. (2016), "What entrepreneurship educators do not understand about creativity and how to teach it", in Morris, M. H., and Liguori, E.W., Teaching Reason and the Unreasonable: Annals of Entrepreneurship Education and Pedagogy, Edward Elgar Publishing, pp. 26-59.

Thorolfsson, M., Finnbogason, G. and Macdonald, A. (2012), “A perspective on the intended science curriculum in Iceland and its 'transformation' over a period of 50 years", International Journal of Science Education, Vol. 34 No. 17, pp. 2641-2665,

DOI:10.1080/09500693.2012.731542

Tschannen-Moran, M., Salloum, S.J. and Goddard, R.D. (2014), “Context Matters: The Influence of Collective Beliefs and Norms", in Fives, H. and Gill, M.G., (Eds.) International Handbook of Research on Teachers' Beliefs, Routledge, New York, NY, pp. 301-316.

UNESCO (2003), The Decade of Education for Sustainable Development: framework for a draft international implementation scheme, Paris, UNESCO.

Vanevenhoven, J. (2013). "Advances and challenges in entrepreneurship education", Journal of Small Business Management, Vol. 51, No. 3, pp. 466-470.

Wallace, C. S., and Priestley, M. (2011), "Teacher beliefs and the mediation of curriculum innovation in Scotland: A socio-cultural perspective on professional development and change", Journal of Curriculum Studies, Vol. 43 No. 3, pp. 357-381.

World Economic Forum (2012), Global Education Initiative Retrospective on Partnerships for Education Development 2003-2011, Author, Geneva.

Yamakawa, Y., Hunt, J., McKone-Sweet, J., and Greenberg, D. (2016), "Expanding the focus of entrepreneurship education: A pedagogy for teaching the entrepreneurship method", Journal of Business and Entrepreneurship Vol. 27, No. 2, pp.19-46.

Zhao, Y. (2012), World class learners: Educating Creative and Entrepreneurial Students, Thousand Oaks, Corvin Press. 
